Ethiopian Journal of Environmental Studies \& Management 9 (1): 14 - 21, 2016.

ISSN:1998-0507

doi: http://dx.doi.org/10.4314/ejesm.v9i1.2

Submitted: May 11, 2015

Accepted: January 05, 2016

\title{
VARIATION IN THE QUALITY OF UPGRADED SLUMS IN LAGOS, NIGERIA
}

\author{
ADEDAYO, A.F. AND *MALIK, N.A.
}

Department of Geography and Environmental Management, University of Ilorin

\begin{abstract}
This paper examines the variation in the quality of nine (9) upgraded slums in Lagos metropolis using two scales of measurement structured around 16 variables. Data used for this study were collected from primary and secondary sources. The primary data was sourced from questionnaire administration. A total of one hundred and twenty (120) respondents in each of the nine (9) upgraded slums were selected through systematic-random technique. The information collected was analyzed with tables, percentages and Analysis of variance. The results of the dwelling type revealed that over $80 \%$ of the respondents in all the slums lived in a room/room and parlour while hand-dug well and borehole were the common sources of water. In addition, buildings with inadequate drainage facilities as revealed by respondents were also areas with high rate of flooding. These include Agege, Makoko and Iwaya with $71.7 \%, 74.8 \%$ and $60 \%$ of buildings respectively prone to flood. A multiple comparison of housing quality between Agege and the other eight slums indicated that Ajegunle and Itire/ljeshatedo had better housing conditions while Agege was better off in housing quality than Makoko. Ajegunle had better quality housing than the slums of Badia, Iwaya and Makoko with Amukoko housing of considerable high quality compared to those in Badia, Iwaya and Makoko. The results of the ANOVA revealed that variation in housing quality is not significant at 0.05 . This showed that there are no significant differences in housing quality in the study area while variation in environmental quality is significant at 0.05.This shows that significant differences existed in variables used to measure environmental quality in the study area.
\end{abstract}

Key Words: Slums, Quality, spatial Difference, Lagos, Nigeria

\section{Introduction}

Cities are generally places of intensive human activities. The city environment therefore is often characterized by complex economic, social and cultural activities that create consequently many difficulties and concomitant problems. These problems relate to transportation, waste generation, unemployment, housing, health among others. One of such problems relating to housing is the proliferation of illegal or

*Corresponding Author: Malik, N.A.

Email: today_2009@yahoo.com informal settlements regarded as ghettos, squatter settlement or slums. The term 'slum' is given various meanings across different geographical areas. Some of these are: favelas of Brazil, chawls zopadpatttis of Mumbai, (India), the bustees of Kolkata (India), the colonias populares of Mexico City, the intra-murios of Rabat (Morocco), the katchi abadis of Karachi (Pakistan), the bidonvilles of Abidjan (Cote D'lvoire) and 
baladis of Cairo, Egypt (UN-HABITAT, 2003).

Slums are captured by the majority as settlements outside the planned cities and their inhabitants as outside the society. Francoise (2006) describes the slum as a place with high prevalence of lawless and illegal activities. He identified four phases in the approach to slums. The first phase (1950s-1970s) identified the slums as being the result of transitional process generated by a strong rural exodus. During this period, urban managers justified the destruction of slums by making reference to dual ideologies of modernization and decolonization. The second phase which started from 1970s onwards witnessed the upgrading of slums as strategies towards uplifting the standards of these precarious neighbourhoods. However, these promotions were spearheaded by international organizations like UNICEF and World Bank. The third phase from 1990s focused on strategies towards slum rehabilitation and resettlement. This concern emerges from the growing consciousness of the extreme environmental degradation in slums and the resulting risks for residents. The fourth was summarized in the UN-HABITAT Declaration, 2004/2005 which aims to combat poverty and improve the housing conditions of at least 100 million slum dwellers by 2020. The improvement of slum residents living conditions through upgrading programmes of Lagos state government was reflected in improved method of refuse disposal, provision of pipe-borne water, construction of roads and drainages among others (Adedayo and Malik, 2014).

The slums of the world especially in developing countries are manifestations of spatial and environmental inequalities with features of deprivation, unemployment, social exclusion, disease, crime and insecurity. This supports the findings of Makinwa-Adebusoye (1988) study in Lagos slum of Olaleye-Iponri which was characterized by bucket-type of toilet shared bathroom and kitchen facilities and houses not connected to pipe borne water. However, these slums are also centres of economic and social opportunities through the provision of low-cost labour for the public and private production of goods and services as well as providing a social network of support for migrants (Francoise 2006). Hence, the UN-HABITAT proposes a dual classification of slums. These are: classification linking it to neighbourhood suffering a process of degeneration and as settlements undergoing transformation and improvement.

The growth of slums in Lagos state results from the population, size and age of existence. Presently, the number of slum areas in Lagos is over forty-two (UN HABITAT, 2003). This confirms UN HABITAT (2003) research that 327 million people live in slums in Commonwealth countries, that is, one out of six Commonwealth citizens as well as a quarter of Commonwealth countries (11 Africans; 2 Asians and 1 Pacific).

A great challenge facing Lagos Metropolis is shelter (Abiodun, 1976) particularly for people living in overcrowded slums. The estimates from official records put the population density at 1,308 persons per square kilometers with the available land falling prey to unregulated and unplanned development. The problem of insecure land tenure defined by the inability of the slum residents also contributes to the growth of and the poor sanitation condition of the slums. The common practices of bulldozing the slum environment exemplified by the Maroko case of 1990 
do not proffer the best solution to the proliferation of slums. The victims of this bulldozer were neither resettled nor compensated. This has been the agitation of non-governmental organizations such as social and economic rights action (SERAC) and centre on human rights and evictions (COHRE) to defend the plight of these victims of eviction. This was substantiated by Agbola and Jinadu (1997) findings that the maroko residents forcefully evicted were legal occupants who government had issued certificate of occupancy legitimizing their stay before eventual demolition. The spatial variability in the quality of nine (9) upgraded slums of Lagos metropolis therefore constitutes the rationale for this study.

\section{Study Area}

The upgraded slums in metropolitan Lagos are the focus of this study. Lagos

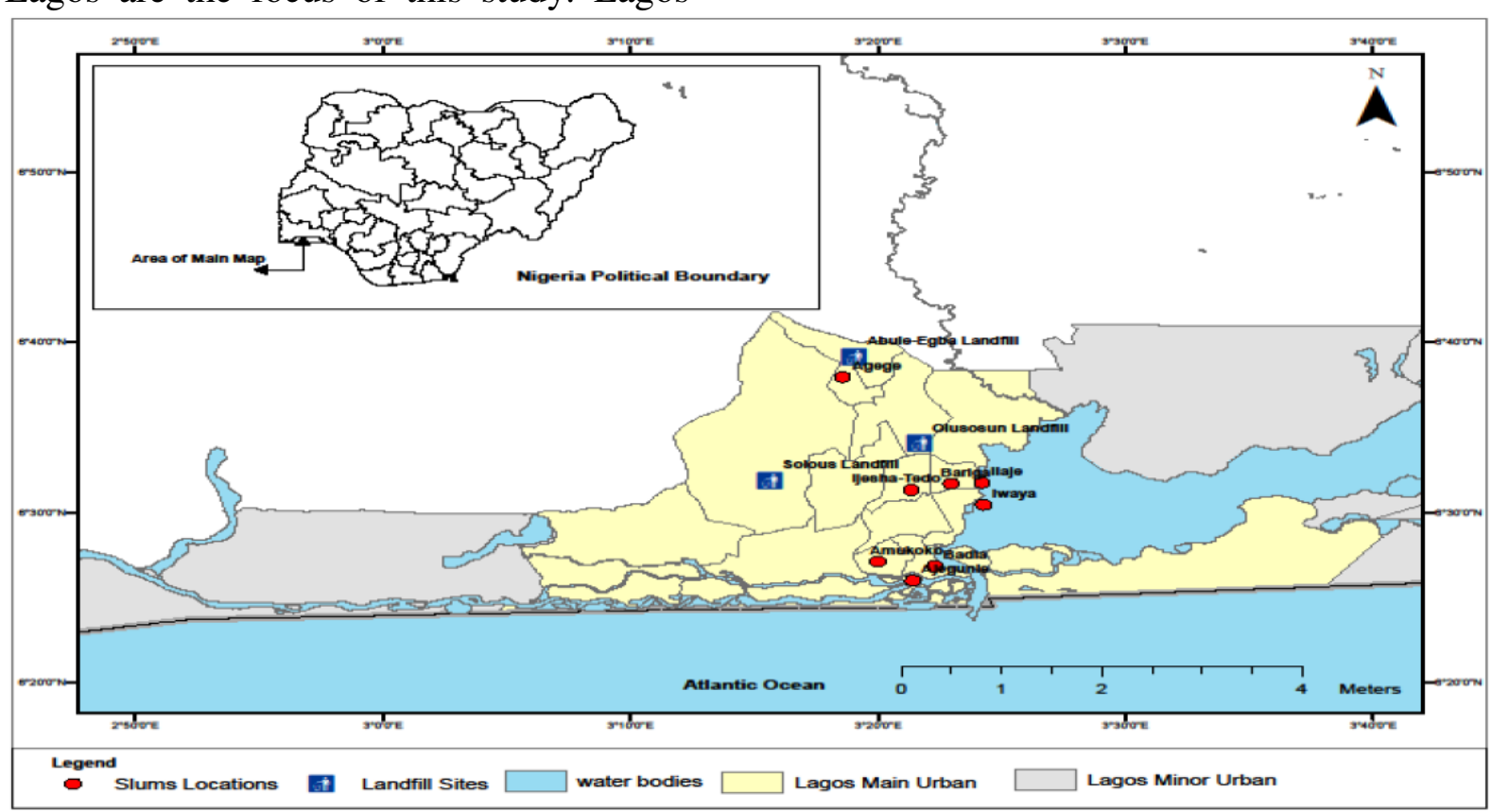

Figure 1: Slums upgraded in Lagos Metropolis

Source: Produced by Cartography section, Geography\& planning department, Lagos State University, 2014

\section{Methods of Research}

Data used for this study were collected from primary and secondary sources. The primary data was collected through
State is located in the south-western part of Nigeria. It lies approximately between longitudes $2^{0} 42^{\prime} \mathrm{E}$ and $3^{0} 42^{\prime} \mathrm{E}$ and latitudes $6^{0} 22^{\prime} \mathrm{N}$ and $6^{0} 52^{\prime} \mathrm{N}$. There are 1,620 hectares of land covered by the 42 slums identified by United Nations study of 1984 which employed thirty-six indicators to measure access to basic infrastructural and social services. However, with the support of Norwegian Government and International Development Association, the Lagos State Government through its agency called Lagos Metropolitan Development and Governance project (LMDGP) has upgraded nine (9) out of the forty-two identified in 1984. The nine slums covered 760 hectares representing 46.1 percent of the total number of slums (Figure 1). 
selected through systematic-random technique. The administration of the questionnaire started by pure random selection of the first house (starting point) and proceeded progressively at an interval of five houses on a street. Information on map of the study area and review of relevant literature through journals, textbooks and the internet constitute the secondary data sources. The information collected was analyzed through the use of tables, percentages and Analysis of variance was used to test the significant differences in the quality of the slum areas.

\section{Results and Discussion}

Table 1 reveals the quality of slum housing in relation to materials used for building construction and dwelling types occupied by respondents. The finding shows that $99.2 \%, 98.3 \%, 86.7 \%$ and 76.7\% of buildings in Amukoko, Ajegunle, Ilaje and Makoko respectively were constructed with bricks. However, 23.3\%, $15 \%$ and $10.8 \%$ of buildings at Makoko, Iwaya and Ilaje respectively were constructed with wooden materials. The implication of buildings constructed with wooden materials is the risk of fire. This was discovered during the field study when an area popularly known as Ilaje-Ebute at Ilaje slum area was completely razed down by fire (see plates $1 \mathrm{a} \& 1 \mathrm{~b}$ ).

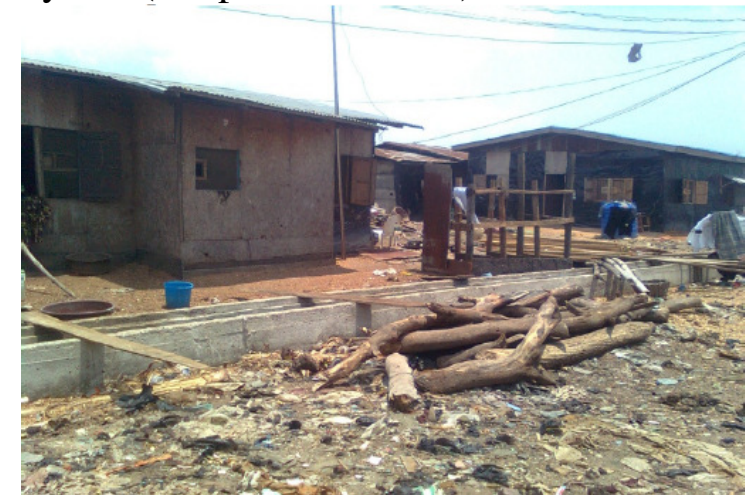

Plate 1a: Ilaje- Ebute before Fire Incident

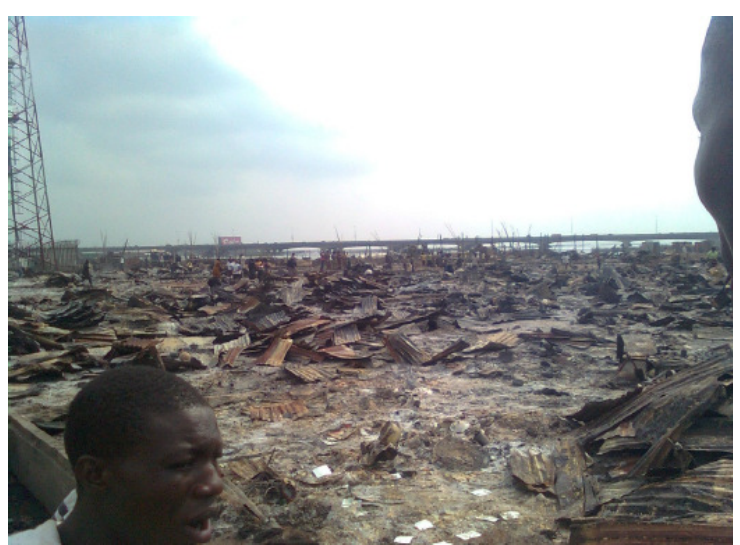

Plate 1b: Ilaje- Ebute after Fire Incident

Table 1: Construction Materials for Slum Dwellings

\begin{tabular}{|c|c|c|c|c|c|c|c|}
\hline \multirow[t]{2}{*}{ Slum Areas } & \multicolumn{3}{|c|}{ Construction materials } & \multicolumn{3}{|c|}{ Dwelling type } & \multirow[b]{2}{*}{ Room } \\
\hline & Bricks & Mud & Wood & Duplex & Flat & Room \& parlour & \\
\hline Agege & $100(83.3 \%)$ & $20(16.7 \%)$ & & & $04(3.3 \%)$ & $36(30.0 \%)$ & $80(66.7 \%)$ \\
\hline Ajegunle & 118(98.3) & $02(1.7 \%)$ & & & $15(12.5 \%)$ & $63(52.5 \%)$ & $42(35.0 \%)$ \\
\hline Amukoko & $119(99.2 \%)$ & $01(0.8 \%)$ & & & $17(14.2 \%)$ & $82(68.3 \%)$ & $21(17.5 \%)$ \\
\hline Badia & $120(100 \%)$ & & & & $08(6.7 \%)$ & $70(58.3 \%)$ & $42(35.0 \%)$ \\
\hline Bariga & $120(100 \%)$ & & & & $10(8.3 \%)$ & $61(50.8 \%)$ & $49(40.8 \%)$ \\
\hline Ilaje & $104(86.7 \%$ & $03(1.7 \%)$ & $13(10.8 \%)$ & $01(0.8 \%)$ & $16(13.3 \%)$ & $37(30.8 \%)$ & $66(55.0 \%)$ \\
\hline Itire/Ijeshatedo & $120(100 \%)$ & & & $01(0.8 \%)$ & $12(10.0 \%)$ & $77(64.2 \%)$ & $30(25.0 \%)$ \\
\hline Iwaya & $100(83.3 \%)$ & $02(1.7 \%)$ & $18(15.0 \%)$ & & $05(4.2 \%)$ & $64(53.3 \%)$ & $51(42.5 \%)$ \\
\hline Makoko & $92(76.7 \%)$ & & $28(23.3 \%)$ & & $04(3.3 \%)$ & $64(53.3 \%)$ & $52(43.3 \%)$ \\
\hline
\end{tabular}

The dwelling type occupied by respondents revealed that very few lived in flats. The families (households) who lived in flats were $14.2 \%, 13.3 \%$ and $12.5 \%$ for Amukoko, Ilaje and Ajegunle slum areas respectively. Furthermore, the household 
who occupied two rooms (room and parlour) were common in the slum areas of Amukoko, Itire/Ijeshatedo, Badia and Ajegunle representing 68.3\%, 64.2\%, $58.3 \%$ and $52.5 \%$ of respondents respectively.

The implication of this is that majority of the respondents tend to live with people of their own status where accommodation can be easily assessed. This is in support of the view expressed by Okeke (1984) when he described the slum inhabitants as agglomeration of people from different ethnic background who are self conscious about their differences from the rest of the urban community and thus resolved to live very close to people of their own status.
Table 2 shows that $25 \%, 23.3 \%, 20.8 \%$ and $20 \%$ of respondents in Bariga, Badia, Ilaje and Iwaya respectively made use pipe borne water. The access of respondents to this source of water could be attributed to the presence of Micro water scheme in these slum areas. In addition, 56.7\%, $55.8 \%, 51.7 \%$ and $45 \%$ of respondents in Itire/Ijeshatedo, Agege, Amukoko and Badia respectively claimed that their source of water was through wells. Despite the risk associated with water purchased from water vendors, this was still prominent in the slum areas of Makoko and Ilaje where $50 \%$ and $45.8 \%$ of respondents respectively purchase water for domestic uses through water vendors.

Table 2: Water and Waste Disposal Facility in the Slums

\begin{tabular}{|c|c|c|c|c|c|c|c|c|}
\hline \multirow[t]{2}{*}{ Slum Areas } & \multicolumn{3}{|c|}{ Source of water } & \multicolumn{5}{|c|}{ Refuse disposal } \\
\hline & Tap water & Borehole & Well & Water vendor & Landfill & Incinerate & Lawma/Psp & Open space \\
\hline Agege & $02(1.7 \%)$ & $24(20.0 \%)$ & $67(55.8 \%)$ & $27(22.5 \%)$ & $01(0.8 \%)$ & & $119(99.2 \%)$ & \\
\hline Ajegunle & $09(7.5 \%)$ & $69(57.5 \%)$ & $34(28.3 \%)$ & $08(6.7 \%)$ & $02(1.7 \%)$ & & $118(98.3 \%)$ & \\
\hline Amukoko & & $43(35.8 \%)$ & $62(51.7 \%)$ & $15(12.5 \%)$ & & & $120(100 \%)$ & \\
\hline Badia & $28(23.3 \%)$ & $32(26.7 \%)$ & $54(45.0 \%)$ & $06(5.0 \%)$ & $03(2.5 \%)$ & & $117(97.5 \%)$ & \\
\hline Bariga & $30(25.0 \%)$ & $39(32.5 \%)$ & $23(19.2 \%)$ & $26(23.3 \%)$ & & $02(1.7 \%)$ & $82(68.3 \%)$ & $36(30.0 \%)$ \\
\hline Ilaje & $25(20.8 \%)$ & $28(23.3 \%)$ & $12(10.0 \%)$ & $55(45.8 \%)$ & $19(15.8 \%)$ & $04(3.3 \%)$ & $90(75.0 \%)$ & $07(5.8 \%)$ \\
\hline Itire/Ijeshatedo & $14(11.7 \%)$ & $31(25.8 \%)$ & $68(56.7 \%)$ & $07(5.8 \%)$ & & & $119(99.2 \%)$ & $01(0.8 \%)$ \\
\hline Iwaya & $24(20.0 \%)$ & $56(46.7 \%)$ & $12(10.0 \%)$ & $28(23.3 \%)$ & $10(8.3 \%)$ & & $95(79.2 \%)$ & $15(12.5 \%)$ \\
\hline Makoko & $01(0.8 \%)$ & $50(41.7 \%)$ & $09(7.5 \%)$ & $60(50.0 \%)$ & $02(1.7 \%)$ & $01(0.8 \%)$ & $77(64.2 \%)$ & $40(33.0 \%)$ \\
\hline
\end{tabular}

The common method of refuse disposal was through the Lagos State Waste Management Authority (LAWMA) trucks and dustbins in partnership with private organizations. Table 2 further reveals that $98.3 \%, 99.2 \%, 97.5 \%$ and $64.2 \%$ of respondents in Ajegunle, Agege, Badia and Makoko respectively disposed their refuse through LAWMA trucks. This implied that the slum residents (respondents) had access to improved method of refuse disposal which may likely translate to improved rate of environmental cleanliness in the slum areas. However, the practice of disposing refuse in open spaces was still common in Bariga and Makoko where
$33 \%$ and $30 \%$ of respondents respectively claimed to dispose their refuse in open spaces.

Drainage facility is essential in building in order to ensure a healthy and clean environment. The slum buildings without drainage facility were more pronounced in the slum areas of Agege, Makoko and Iwaya with $71.7 \%, 57.5 \%$ and $47.5 \%$ of buildings surveyed. In addition, majority of the slum areas with drainage facilities were either stagnant or blocked. Table 2 further reveals that 45\%, 55\%, $42.5 \%$ and $41.7 \%$ of drainage facility in the slums of Badia, Amukoko, Ilaje and Bariga were either blocked or stagnant. 
Table 3: Drainage Facility and Flooding Status

\begin{tabular}{lccccc}
\hline Slum Areas & \multicolumn{3}{c}{ Drainage } & \multicolumn{2}{c}{ Flooding rate } \\
& No & Flow & Stagnant \&block & Prone & Not prone \\
\hline Agege & $86(71.7 \%)$ & $05(4.1 \%)$ & $29(24.2 \%)$ & $86(71.7 \%)$ & $34(28.3 \%)$ \\
Ajegunle & $30(25 \%)$ & $31(25.8 \%)$ & $59(49.2 \%)$ & $20(16.7 \%)$ & $100(83.3 \%)$ \\
Amukoko & $12(10 \%)$ & $66(55 \%)$ & $42(35.0 \%)$ & $16(13.3 \%)$ & $104(86.7 \%)$ \\
Badia & $43(35.8 \%)$ & $54(45.0 \%)$ & $23(19.2 \%)$ & $69(42.5 \%)$ & $51(57.5 \%)$ \\
Bariga & $29(24.2 \%)$ & $50(41.7 \%)$ & $41(34.1 \%)$ & $67(55.9 \%)$ & $53(44.1 \%)$ \\
Ilaje & $13(10.8 \%)$ & $51(42.5 \%)$ & $56(46.7 \%)$ & $55(45.8)$ & $65(54.2 \%)$ \\
Itire/Ijeshatedo & $18(15 \%)$ & $33(27.5 \%)$ & $69(57.5 \%)$ & $41(34.2 \%)$ & $79(65.8 \%)$ \\
Iwaya & $57(47.5 \%)$ & $25(20.8 \%)$ & $38(31.6 \%)$ & $72(60 \%)$ & $48(40 \%)$ \\
Makoko & $69(57.5 \%)$ & $19(15.8 \%)$ & $32(26.7 \%)$ & $89(74.8 \%)$ & $31(25.8 \%)$ \\
\hline
\end{tabular}

Flooding is induced by both natural and human factors. One major human factor that could cause flooding in the built environment is non-availability and nonfunctionality of drainage system. This explains the relationship between flooding and drainage facility in the slums. Table 3 reveals that $71.7 \%, 74.8 \%$ and $60 \%$ of respondents respectively in Agege, Makoko and Iwaya slum areas claimed that their buildings were prone to flooding. However, $83.3 \%, 86.7 \%$ and $65.8 \%$ of respondents respectively in Ajegunle, Amukoko and Itire/Ijeshatedo slums indicated that their buildings were not susceptible to flood.

\section{Variation in the Quality of Slum Areas}

Two indicators with respect to housing quality and environmental quality were used to examine the differences that existed in the surveyed upgraded slum areas. These are: housing quality measured by eleven variables and environmental quality by five variables. The variables include: dwelling type occupied by respondents, materials used for slum building, source of water, toilet type, drainage type, and refuse disposal method among others.

Analysis of variance (ANOVA) was used to test if there are significant differences in housing quality in the slum areas. The result in Table 4 revealed that variation in housing quality is not significant at 0.05 . This shows that there are no significant differences in housing quality in the study area. The implication of this is that the slums exhibit similarity in the variables used to measure the housing quality. For instance, the findings reveals that majority of the respondents lived in two rooms (room and parlour) or one room and share bathroom and kitchen facilities. This was the findings of similar study earlier conducted by Makinwa-Adebusoye (1988) in olaleye-Iponri slum with majority of the houses investigated using pit latrine and share bathroom and kitchen facilities.

Table 4: Analysis of Variance (ANOVA)

\begin{tabular}{|c|c|c|c|c|}
\hline & & Sum of Squares & f Mean Square & \\
\hline \multirow[t]{3}{*}{$\overline{\text { HOUSING QUALITY SCORE }}$} & Between Groups & 289.6378 & $8 \quad 36.205$ & .954 .471 \\
\hline & Within Groups & 40653.2141071 & 37.958 & \\
\hline & Total & 40942.8511079 & 79 & \\
\hline \multirow[t]{2}{*}{ ENVIRONMENTAL QUALITY SCORE } & $\begin{array}{l}\text { Between Groups } \\
\text { Within Groups }\end{array}$ & $\begin{array}{rr}9.315 & 8 \\
96.540 & 1071\end{array}$ & \multirow{2}{*}{\multicolumn{2}{|c|}{$\begin{array}{l}1.16412 .917 .000 \\
.090\end{array}$}} \\
\hline & Total & 105.8551079 & & \\
\hline
\end{tabular}


Furthermore, analysis of variance (ANOVA) result in Table 4 reveals that variation in environmental is significant at 0.05.This shows that significant differences existed in variables used to measure environmental quality in the study area. The findings on drainage type showed variations in the number of buildings in the slum areas without drainage facilities and buildings that were prone to flooding (see Table 3). In addition, the habit of dumping refuses in open spaces features prominently in some slum areas which make the degree of environmental cleanliness in the slums vary significantly.
Multiple comparisons was done in order to show disparities that existed in housing facilities used as indices to measure housing quality in the study area. The comparison was done between a slum settlement in relation to others. Hence, the comparison between Agege and the other eight slums indicated that Ajegunle and Itire/Ijeshatedo had better housing conditions while Agege was better off in housing quality than Makoko. Also, Ajegunle had better housing facilities as compared to the slums of Badia, Iwaya and Makoko. However, Amukoko housing units were of considerable high quality compared to those in Badia, Iwaya and Makoko.

Table 5: Housing quality comparisons for Agege, Ajegunle and Amukoko slums

\begin{tabular}{|c|c|c|c|c|c|}
\hline $\begin{array}{l}\text { Dependent } \\
\text { Variable }\end{array}$ & $\begin{array}{l}\text { (I) Name of } \\
\text { Slum }\end{array}$ & (J) Name of Slum & $\begin{array}{l}\text { Mean } \\
\text { Difference } \\
(\mathrm{I}-\mathrm{J})\end{array}$ & Std. Error & Sig. \\
\hline \multirow{24}{*}{$\begin{array}{l}\text { HOUSING } \\
\text { QUALITY } \\
\text { SCORE }\end{array}$} & \multirow[t]{8}{*}{ Agege } & Ajegunle & $-.06818^{*}$ & .02047 & .036 \\
\hline & & Amukoko & -.03561 & .02136 & .970 \\
\hline & & Badia & .04212 & .02235 & .885 \\
\hline & & Bariga & -.00985 & .02156 & 1.000 \\
\hline & & Ilaje & -1.63258 & 1.6868 & 1.000 \\
\hline & & Itire/Ijeshatedo & $-.08712^{*}$ & .02000 & .001 \\
\hline & & Iwaya & .05909 & .02470 & 0.462 \\
\hline & & Makoko & $.12636^{*}$ & .02415 & .000 \\
\hline & \multirow[t]{8}{*}{ Ajegunle } & Agege & $.06818^{*}$ & .02047 & .036 \\
\hline & & Amukoko & .03258 & .01842 & .939 \\
\hline & & Badia & $.11030^{*}$ & .01956 & .000 \\
\hline & & Bariga & .05833 & .01865 & .068 \\
\hline & & Ilaje & -1.56439 & 1.68677 & 1.000 \\
\hline & & Itire/Ijeshatedo & -.01894 & .01683 & 1.000 \\
\hline & & Iwaya & $.12727^{*}$ & .02221 & .000 \\
\hline & & Makoko & $.19455^{*}$ & .02160 & .000 \\
\hline & \multirow[t]{8}{*}{ Amukoko } & Agege & .03561 & .02136 & .970 \\
\hline & & Ajegunle & -.03258 & .01842 & .939 \\
\hline & & Badia & $.07773^{*}$ & .02049 & .007 \\
\hline & & Bariga & .02576 & .01962 & .999 \\
\hline & & Ilaje & -1.59697 & 1.68678 & 1.000 \\
\hline & & Itire/Ijeshatedo & -.05152 & .01790 & .144 \\
\hline & & Iwaya & $.09470^{*}$ & .02304 & .002 \\
\hline & & Makoko & $.16197^{*}$ & .02244 & .000 \\
\hline
\end{tabular}

The quality of housing in Badia was of less value as compared to Ajegunle, Amukoko and Itire/Ijeshatedo. However, the housing quality in Makoko was of low standard to that of Badia. Itire/Ijeshatedo was characterized by better housing with reference to Badia, Bariga, Iwaya and Makoko. However, Iwaya housing status was of low quality to the slums that Ajegunle, Amukoko and Itire/Ijeshatedo. 


\section{Conclusion}

This study has established from the slum residents responses to questionnaire and field observation that spatial differences exist in the environmental quality of the nine (9) upgraded slums of Lagos metropolis. The upgrading programmes of the state government such as dredging of canals, waste disposal trucks for refuse disposal has improved the environmental condition of the slums. Despite these efforts, a lot of improvement in the quality of the environment of these slums is required. This study thus recommends that slum upgrading programmes in slums should be sustained, encouraged and incorporated into Lagos state policy and beyond.

\section{References}

Abiodun, O.J. (1976). Housing problems in Nigerian Cities. Town Planning Review, 47(4):330-348

Adedayo, A.F. and Malik, N.A. (2014). Effects of Urban Renewal Programmes on the Slum Residents of Lagos Metropolis, Nigeria. Journal of Sustainable Development in Africa, 16(8):30-43

Agbola, T. and Jinadu, A.M. (1997). "Tenants addressing the needs, increasing options" In Environment and Urbanization, 9(2): 271-289.

Francoise Lieberherr-gardiol (2006). Slums forever? Globalisation and Its
Consequences. The European Journal of Development Research, 18(2): 275-283.

Makinwa-Adebusoye, P.K. (1988). "Managing the Urban Environment: A strategy for upgrading OlaleyeIponri Slum in Lagos Metropolitan Area" in Sada, P.O. and Odemerho, F.O. (eds.) Environmental Issues and Management in Nigeria

Development. Evans Brothers. Pp 132-147

Okeke, D.C. (1984). "A renewal programme for urban centre of Enugu", Unpublished M.Sc. Dissertation submitted to the Department of Urban and Regional Planning, Obafemi Awolowo University, Ile- Ife, Nigeria

Onokerhoraye, A.G. (1988). "Case studies of urban slums and environmental problems in Nigerian cities". in Sada, P.O. and Odemerho, F.O. (eds.) Environmental Issues and Management in Nigerian Development. Evans Brothers. Pp 118-131.

UN-HABITAT (2003). The Challenge of Slums: Global report on human settlements. London, Earthsean Publications Ltd.

UN-HABITAT, 2004/2005, The State of the World's Cities, Globalization and Urban Culture. London: EarthScan. 